\title{
A Defense of Empirical Legal Scholarship
}

\author{
Richard L. Revesz†
}

Lee Epstein and Gary King, two distinguished social scientists, mount a forceful attack on empirical legal scholarship.' According to Epstein and King, "the current state of empirical legal scholarship is deeply flawed" and has "little awareness of, much less compliance with, the rules of inference that guide empirical research in the social and natural sciences." They characterize this problem as universal:

[I]n deciding whether to write this Article, we conducted our own survey of current practices in the nation's law reviews. Our purpose was to identify where the problems were. Our answer? Everywhere. We find that serious problems of inference and methodology abound everywhere we find empirical research in the law reviews and in articles written by members of the legal community. ${ }^{3}$

Moreover, Epstein and King maintain that empirical legal scholarship does not pay attention to methodological issues: "The sustained, self-conscious attention to the methodology of empirical analysis so present in the journals in traditional academic fields ... is virtually nonexistent in the nation's law reviews." This problem, they believe, is also universal: "[T]he complete list of all law review articles devoted to improving, understanding, explicating, or adapting the rules of inference is as follows: none.".

Epstein and King's solution is to place empirical legal scholarship in a type of intellectual receivership, in which law professors get sent to the functional equivalent of a reeducation camp. ${ }^{6}$ Here, they will be required to follow the precepts set forth by Epstein and King and receive remedial instruction from social scientists. According to Epstein and King: "Learning and understanding the rules we discuss in this Article are, we believe, necessary steps for law professors to take. Yet,

\footnotetext{
$\dagger$ Lawrence King Professor of Law, New York University School of Law. I am grateful for the comments of Vicki Been, Charles Cameron, Jules Coleman, Robert Daines, John Ferejohn, Barry Friedman, and Daryl Levinson, and for the research assistance of Elizabeth Rohlfing. The Filomen D'Agostino and Max E. Greenberg Research Fund at the New York University School of Law provided financial support.

1 Lee Epstein and Gary King, The Rules of Inference, 69 U Chi L Rev 1 (2002).

2 Id at 6.

3 Id at 15.

4 Id at 6.

5 Id at 11.

6 Id at 114-33.
} 
at the same time, we acknowledge that these steps alone are insufficient, and that legal academics will require additional training to implement the rules we have offered." Epstein and King think that the consequences of not taking their work seriously will be dire: empirical legal scholarship will remain deeply flawed "if th[eir] Article is not read." $"$

In the past twenty years, the legal academy has become quite interdisciplinary in its ambitions and methods. It is therefore natural that scholars in other disciplines-particularly the social scienceswould want to assess the quality of work being done by legal scholars, as Epstein and King have done. At the same time, given the extent to which joint degree holders and otherwise academically trained individuals have moved into legal teaching, it would be surprising if the quality of legal research-particularly empirical research-had not improved dramatically over time, with its tools becoming more sophisticated, the questions it addresses becoming better conceived, and its results becoming more illuminating. Surprisingly, after engaging in what they take to be an exhaustive review of the literature, Epstein and King conclude that the results are grim. As already indicated, they find much to condemn and little to applaud in the current scholarly output of legal academics performing empirical work.

This brief response proceeds as follows. Parts I and II focus on my work on judicial behavior in the D.C. Circuit,' which Epstein and King criticize as an example of flawed empirical scholarship. ${ }^{10}$ In Part I, I present my D.C. Circuit article as a case study of various categories of methodological advances achieved by empirical legal scholars, and suggest that similar methodological advances can be found elsewhere in legal scholarship. In Part II, I show that Epstein and King's specific criticisms of my D.C. Circuit work are all unwarranted, and raise questions as to whether mine could be the only example of empirical legal scholarship that they attack in an unjustified manner. Part III criticizes the methodology used by Epstein and King to conclude that the benefits of methodological interactions between social scientists and lawyers are all unidirectional-from the social scientists to the lawyers. Part IV takes issue with Epstein and King's portrayal of empirical legal scholarship as disconnected from developments elsewhere in the academy.

The Epstein and King article defines empirical legal scholarship very broadly, in a way that encompasses a great deal of legal scholar-

7 Id at 119.

8 Id at $116 \mathrm{n} 41$.

9 Richard L. Revesz, Environmental Regulation, Ideology, and the D.C. Circuit, 83 Va L Rev 1717 (1997).

10 See Epstein and King, 69 U Chi L Rev at 74-75, 83-85 (cited in note 1). 
ship." My comment is much narrower. It focuses on econometric analyses, and its examples are drawn primarily from studies of judicial behavior. Thus, it does not deal with other important questions raised by Epstein and King, such as whether legal history should be subjected to the methodological standards of the social sciences rather than to the methodological standards of historical research. ${ }^{12}$

The opening of a dialogue between legal scholars and social scientists has been an extremely salutary academic development of the past decades. ${ }^{13}$ The Epstein and King article, with its one-sided criticisms-some clearly unwarranted-threatens to undermine this dialogue. Moreover, in their haste to show that legal academics have failed, Epstein and King miss an important opportunity to explore the ways in which each discipline can contribute to the other. In contrast, I hope that this Response can be a catalyst for useful interdisciplinary interactions.

\section{METHODOLOGICAL ADVANCES IN LEGAL SCHOLARSHIP}

Epstein and King state in no uncertain terms that empirical legal scholarship is wholly unconcerned with questions of methodology, and that no law review article-not a single one-is concerned with "understanding, explicating, or adapting the rules of inference." Perhaps not surprisingly, given the sweeping and incautious nature of their claim, the authors are simply wrong.

I will begin by discussing three important methodological innovations contained in my own empirical study of the D.C. Circuit's treatment of challenges to health and safety regulation. ${ }^{15}$ Because the authors chose to criticize my article at some length, ${ }^{16}$ they must believe that, like all the rest of empirical legal scholarship, it fails to give "sustained, self-conscious attention to the methodology of empirical analysis." "17

11 See Epstein and King, 69 U Chi L Rev at 2-3 (cited in note 1) ("What makes research empirical is that it is based on observations of the world.... These facts may be historical or contemporary, based on legislation or case law, the results of interviews or surveys, or the outcomes of secondary archival research or primary data collection."). They add that "in terms of legal scholarship, it is only the purely normative or theoretical that is not empirical." Id at 3.

12 See id at $42,97-99$.

13 For a useful effort of this type, see Frank B. Cross, Political Science and the New Legal Realism: A Case of Unfortunate Interdisciplinary Ignorance, 92 Nw U L Rev 251 (1997) (urging combination of the political science attitudinal model with legal models in evaluating judicial decisionmaking).

14 Epstein and King, $69 \mathrm{U}$ Chi L Rev at 11 (cited in note 1).

15 Revesz, 83 Va L Rev 1717 (cited in note 9).

16 Epstein and King, $69 \mathrm{U}$ Chi L Rev at 74-75, 83-85 (cited in note 1).

17 See id at 6. 


\section{A. Priest-Klein Effects}

First, my study of the D.C. Circuit pays close attention to the possibility that changes in the ideological composition of a court will have effects on the mix of cases presented to that court for litigation. ${ }^{18}$ Assume, for example, that the composition of a court shifts over time from being predominantly composed of Republican-appointed judges to being predominantly composed of Democrat-appointed judges. (For expository simplicity, judges appointed by Democratic presidents will be referred to as Democratic judges, and judges appointed by Republican presidents will be referred to as Republican judges.)

Let us also assume that Republican judges are more likely than Democratic judges to vote in favor of industry groups challenging environmental regulation as too stringent. Conversely, let us assume that Democratic judges are more likely than their Republican counterparts to vote in favor of environmental groups challenging environmental regulation as too lax. What are the consequences for the types of cases litigated before the court if the composition shifts from a majorityDemocratic composition in Time 0 to a majority-Republican composition in Time 1 ?

One consequence might be that industry groups would pursue weaker cases at Time 1 than at Time 0 because, holding constant the quality of the case, they have a greater probability of prevailing. Thus, cases that would not have been worth bringing in Time 0 , given their expected payoff and the cost of litigation, are worth bringing in Time 1. The proportion of cases in which industry groups prevail might not change over time, because the higher probability of success that results from the more sympathetic panels is counteracted by the lower probability of success that results from the lesser average quality of the cases they litigate."

The rightward shift of the judges also has an effect on settlements. Under the model developed in the influential article by George Priest and Benjamin Klein, cases with either very high or very low probabilities of success are likely to be settled rather than litigated. ${ }^{20}$ The model predicts that the litigated cases would be less clear-cut; under certain relatively restrictive conditions, in fact, in the universe of litigated

18 Revesz, 83 Va L Rev at 1721-27 (cited in note 9).

19 See Richard L. Revesz, Litigation and Settlement in the Federal Appellate Courts: Impact of Panel Selection Procedures on Ideologically Divided Courts, 29 J Legal Stud 685, 707-08 (2000).

20 See George L. Priest and Benjamin Klein, The Selection of Disputes for Litigation, $13 \mathbf{J}$ Legal Stud 1, 15 (1984) (demonstrating that "closer" cases have a wider variance in the parties' estimation of plaintiff's chances for victory and thus are more likely to be litigated). In such cases, the parties are likely to differ less in their estimates of the plaintiff's (or appellant's) probability of success. See id. 
cases, the probability that plaintiffs prevail is 50 percent regardless of the composition of the court. ${ }^{21}$ Under the predictions made by the Priest-Klein model, the rightward shift in the votes of judges changes the mix of litigated cases but not the probability that plaintiffs will prevail. $^{2}$

These case-selection effects create difficulties for the design of empirical studies that seek to determine whether the votes of judges are influenced by their ideologies. In the preceding example, if the proxy used for a judge's ideology were the views generally held by the party of the appointing president, one would expect that the court would be more sympathetic to industry challenges at Time 1 than at Time 0 . Were it not for case-selection effects, one would expect that the industry groups would prevail in a greater proportion of the cases at Time 1. But, as explained above, such an effect might not be observed even if judges vote consistent with their ideology because the change in the composition of the court also affects the mix of litigated cases.

Thus, any empirical technique that does not control for caseselection effects is biased against finding evidence consistent with the hypothesis that judges vote ideologically. The social science literature on judicial politics largely overlooks this complication; it simply aggregates voting records over time without controlling for possible changes in the mix of cases reaching the court. ${ }^{23}$ This problem is most serious with studies that aggregate cases over long periods of time. ${ }^{24}$

Similar shortcomings are reflected in recent efforts in social science literature to test the hypothesis derived from positive political theory models in which judges vote in an ideologically "strategic" manner, so that they compromise their true preferences to the extent

21 See id at 4-6. For explanations of the circumstances under which the plaintiff's probability of success can deviate from 50 percent, see id at 24-29. See also Daniel Kessler, Thomas Meites, and Geoffrey Miller, Explaining Deviations from the Fifty-Percent Rule: A Multimodal Approach to the Selection of Cases for Litigation, 25 J Legal Stud 233 (1996) (classifying cases by characteristics and correcting for "multimodal" case characteristics in order to explain plaintiffs" lower than 50 percent success rates); Steven Shavell, Any Frequency of Plaintiff Victory at Trial Is Possible, 25 J Legal Stud 493 (1996) (attacking the theory that the litigated plaintiff success rate should be 50 percent).

22 Revesz, 29 J Legal Stud at 707 (cited in note 19).

23 See, for example, Sheldon Goldman, Voting Behavior on the United States Courts of Appeals Revisited, 69 Am Polit Sci Rev 491, 491-93 (1975) (examining nonunanimous appellate court decisions from 1965 to 1971 without correcting for the change in case selection); C. Neal Tate, Personal Attribute Models of the Voting Behavior of U.S. Supreme Court Justices: Liberalism in Civil Liberties and Economic Decisions, 1946-1978, 75 Am Polit Sci Rev 355 (1981) (using an attitudinal model in analyzing Supreme Court decisions without correcting for case-selection effects).

24 For one prominent example, see Robert A. Carp and C.K. Rowland, Policymaking and Politics in the Federal District Courts 14 (Tennessee 1983) (aggregating cases over a forty-fouryear period). 
necessary to avoid legislative reversal. ${ }^{25}$ If judges vote strategically in this manner, a legislative shift to the right would lead to a judicial shift to the right. But, as a result of case-selection effects, industry groups might not win a larger proportion of the cases they litigate. Any empirical technique that looked at the impact of the legislative shift on the success rate of such groups would be biased against finding evidence of strategic voting if it did not control for case-selection effects. ${ }^{26}$

In contrast, in my D.C. Circuit piece, I avoided the Priest-Klein problem by dividing the full universe of cases into subsamples defined by time periods during which the composition of the court was relatively stable. For each such period, the interparty comparison was restricted to the judges who served for the full period. ${ }^{27}$ Because cases are assigned randomly to panels, ideological voting would result in interparty differences in judicial votes.

To illustrate the problem that would arise if the judicial votes were instead analyzed in a single sample, assume, counterfactually, that the court was predominantly Republican in the 1970s and predominantly Democratic in the 1980s. In this scenario, the Republican judges decide a disproportionate number of the cases filed in the 1970s whereas the Democratic judges decide a disproportionate number of the cases filed in the 1980s. Assume further that aggregating the votes of all the judges across all cases decided since 1970 reveals that Republicans are no more likely than Democrats to reverse EPA regulations when the challenger is an industry group. One simply cannot tell from such a statistic whether the same interparty relationship would have been observed if the Republicans and Democrats had decided the same set of cases.

More recently, in an article designed to test whether the ideological voting on the D.C. Circuit is strategic, ${ }^{28} \mathrm{I}$ devised a methodology to control for the effects of case selection when testing for evidence of strategic voting. The standard technique in the political science litera-

25 See, for example, Tony Caporale and Harold Winter, Political Influence over Supreme Court Criminal Procedure Cases, 35 J Econ Beh \& Org 465, 466-67 (1998) (using court cases over a forty-year time period without correcting for case-selection effects); Jeffrey A. Segal, Separation-of-Powers Games in the Positive Theory of Congress and the Courts, 91 Am Polit Sci Rev 28, 29 (1997) (describing the attitudinal model without mentioning possible bias due to caseselection effects); Pablo T. Spiller and Rafael Gely, Congressional Control or Judicial Independence: The Determinants of US Supreme Court Labor-Relations Decisions, 1949-1988, 23 RAND J Econ 463, 478-79 (1990) (acknowledging the possibility of case-selection effects but asserting that the problem is not serious in their sample, and making no attempt to correct for it).

26 I explore the issue at some length in Richard L. Revesz, Congressional Influence on Judicial Behavior?: An Empirical Examination of Challenges to Agency Action in the D.C. Circuit, 76 NYU L Rev 1100,1116-19 (2001).

27 See Revesz, 83 Va L Rev at 1721-27 (cited in note 9).

28 See Revesz, 76 NYU L Rev at 1122-27 (cited in note 26). The article has been available online at <http://papers.ssrn.com/sol3/papers.cfm?abstract_id=271932> since June 2, 2001. 
ture has been to look at how changes in Congress affect the proportion of litigated cases in which a judge rules for a particular type of outcome. ${ }^{29}$ But, as already explained, even if judges vote strategically, the shift caused by congressional changes would be counteracted by case-selection effects, so that no differences in voting patterns might be observed. ${ }^{30}$

Instead of following the standard technique used in the political science literature, I focused on how the interparty difference between the votes of Democratic and Republican judges is affected by changes in the control of the two houses of Congress. In particular, when the two houses of Congress are under divided control, Democratic and Republican judges can vote consistent with their ideologies with less fear of legislative reversal than when the two chambers are under the unified control of one party. Thus, if judges vote strategically, one would expect the interparty voting differences to be greater when Congress is under divided control than when it is under unified control.

This effect is impervious to changes in the mix of cases reaching the courts. Regardless of whether the average quality of litigated cases is relatively stronger or relatively weaker, strategic judges should be expected to be more restrained in voting consistent with their ideologies when the probability of legislative reversal is higher.

My efforts to control for case-selection effects build upon both empirical examinations of the Priest-Klein effect ${ }^{32}$ and a relatively extensive theoretical literature by legal scholars. The possibility of caseselection effects is well understood by economically minded legal scholars. It is therefore not surprising that the empirical legal literature, with which Epstein and King find so much fault, developed methodological innovations to address this problem.

\section{B. Panel Composition Effects}

My work on judicial decisionmaking on the D.C. Circuit pays close attention to the possibility that a judge's vote on a case will be affected by the identity of the remaining judges on a panel. ${ }^{33}$ Thus, the estimations contain a colleague variable, which is 1 if a judge has at least one colleague of the same party on the panel, and 0 otherwise. ${ }^{34}$ Controlling for the composition of the panel is necessary to test the

29 See text accompanying notes $39,83-84$.

See text accompanying notes $25-26$.

See Revesz, 76 NYU L Rev at 1116 (cited in note 26).

See Kessler, Meites, and Miller, $25 \mathrm{~J}$ Legal Stud 233 (cited in note 21).

See Revesz, 83 Va L Rev at 1732-34 (cited in note 9).

34 See id at 1757. I also followed this approach in Revesz, 76 NYU L Rev at 1124 (cited in note 26). 
phenomenon that Judge Posner has termed "go-along voting"-the practice of not dissenting in cases in which a judge's views are inconsistent with those of the panel majority. ${ }^{35}$

My work has shown the importance of paying attention to panel composition effects. A judge's vote on the D.C. Circuit is significantly affected by whether she has at least one colleague of the same party on the panel. ${ }^{36}$ Indeed, I found that "Democratic judges 'vote as Democrats' only when there are at least two Democrats on the panel, and that, similarly, Republican judges 'vote as Republicans' only when there are at least two Republicans on the panel.,"37

The political science literature has not paid attention to this issue. Studies of the Supreme Court do not control for the possibility that a justice's votes will be affected by the changing identity of her colleagues over time; more pertinently, studies of the courts of appeals do not control for the composition of particular panels. This failure has an important negative consequence: it leads to an understatement of the true nature of the ideological divisions on the court. Consider a situation in which a court of appeals that hears cases in three-judge panels chosen at random is evenly divided between Democratic and Republican judges. This hypothetical court is extremely polarized along party lines: industry-groups always prevail before majorityRepublican panels but never prevail before majority-Democratic panels. The judges, however, engage in "go-along voting," so that they never dissent. An empirical study that did not control for the composition of the panel would find no interparty voting differences at all: in randomly assigned panels, Democratic and Republican judges would each vote in favor of the industry's claim in exactly half the cases.

In contrast, an empirical study, like mine, that contained an independent variable for panel composition would find that a Republican judge votes in favor of the industry's claim 100 percent of the time when she has at least one Republican colleague, and 0 percent of the time otherwise. In contrast, a Democratic judge votes in favor of the industry's claim 100 percent of the time when she is the sole Democrat on the panel and 0 percent of the time otherwise. The methodology generally used in the political science literature would miss this evidence of ideological voting.

35 See Richard A. Posner, What Do Judges and Justices Maximize? (The Same Thing Everybody Else Does), $3 \mathrm{~S} \mathrm{Ct}$ Econ Rev 1, 2, 20 (1993) (stating that "go-along voting" maximizes judges' leisure).

36 See Revesz, 83 Va L Rev at 1751-56, 1759-60 (cited in note 9).

37 Id at 1766. For a more recent article (also criticized by Epstein and King) examining the effects of panel composition on the D.C. Circuit, see Frank B. Cross and Emerson H. Tiller, Judicial Partisanship and Obedience to Legal Doctrine: Whistleblowing on the Federal Courts of Appeals, 107 Yale L J 2155, 2173-75 (1998).

38 See, for example, sources cited in notes $23,25$. 
Again, it is not surprising that legal academics would make a methodological innovation of this sort. Legal scholars clearly have a comparative advantage in understanding the inner workings of the judiciary. More importantly, a large proportion of legal scholars, but virtually no social science scholars, have spent a year or more as judicial clerks, working closely with a judge and being in a position to observe the nature of inter-judge interactions.

\section{Attention to the Nature of Legal Arguments}

Empirical legal scholarship also pays attention to the nature of the legal arguments presented to the court. In contrast, what matters for the social science scholars is the relief sought by the parties: a more liberal or conservative outcome.

In my D.C. Circuit study, I tested whether the type of argumentstatutory or procedural-presented to the court affected the nature of the ideological divisions among the judges. The results were stark. Between 1986 and 1994, following the Supreme Court's decision in Chevron USA Inc $v$ Natural Resources Defense Council, Inc, ${ }^{40}$ there were no statistically significant differences in the way in which Democrats and Republicans voted on issues of statutory interpretation. In contrast, for industry challenges, the differences were highly significant with respect to procedural issues. Indeed, for procedural claims, the probability of reversal of the agency decision ranged from 2 percent to 13 percent for panels with two Democrats and one Republican, but ranged from 54 percent to 89 percent for panels with two Republicans and one Democrat. These stark differences would not have been revealed if I had not used an independent variable controlling for the nature of the argument."

The possible constraining effects of law are taken far more seriously in law schools than in social science departments. In part, legal scholarship has evolved out of a legal formalist tradition, which believes that judicial decisions are determined by precedent and are unaffected by a judge's policy preferences. ${ }^{42}$ In contrast, the social science

39 See, for example, sources cited in notes 23,25; text accompanying notes 83-84. An influential book by prominent political scientists describes its methodology as follows: "[W]e may properly speak of a case outcome, as well as a justice's vote, as 'liberal' or 'conservative.' ... For the most part, our specification of the 'liberal' and 'conservative' positions accords with common usage." Jeffrey A. Segal and Harold J. Spaeth, The Supreme Court and the Attitudinal Model 243 (Cambridge 1993).

$40 \quad 467$ US 837 (1984).

41 See Revesz, 83 Va L Rev at 1729-32 (cited in note 9); Revesz, 76 NYU L Rev at 1107 (cited in note 26). For an unpublished manuscript examining whether the reasoning in judicial opinions is motivated by strategic considerations, see Joseph L. Smith and Emerson H. Tiller, The Strategy of Judging: Evidence from Administrative Law, 31 J Legal Stud (forthcoming 2002).

42 See John Ferejohn, Law, Legislation, and Positive Political Theory, in Jeffery S. Banks 
literature on judicial behavior has been generally uninterested in the role of legal argument, which does not play an important role in either of the leading political science models: the attitudinal model, which posits that judges vote sincerely in accordance with their policy preferences, and the strategic model, in which judges are willing to compromise their ideological preferences in order to avoid legislative reversal. ${ }^{43}$

\section{Generalizing the Claim}

I have provided some examples of how my work on the D.C. Circuit extends the methodology used in studies of judicial behavior in the social sciences. Methodological innovations and improvements of this sort are not uncommon among legal academics. Looking only within my family, there is extended, self-conscious attention to methodology in Vicki Been's studies on environmental justice. At the time of her work, a number of empirical studies showed that communities surrounding hazardous waste sites were disproportionately populated by people of color and the poor. ${ }^{45}$ Been's work examined, for the first time, whether the disparity is the product of disproportionate siting or of market dynamics. It posited that the communities surrounding the facility may not have been disproportionately minority or poor at the time the facility located there. Instead, the demographic composition might have changed after the facility was sited, as those who could afford to leave the neighborhood and find housing elsewhere did so and were replaced by individuals seeking cheap housing or barred from other housing by discrimination. ${ }^{46}$

Been's principal article empirically examining the market dynamics hypothesis dwells extensively on methodological questions. ${ }^{47}$ It devotes considerable effort to choosing the relevant geographic unit surrounding the site, and adopts a sophisticated procedure for dealing

and Eric A. Hanushek, eds, Modern Political Economy: Old Topics, New Directions 191, 194 (1995) (listing the operative principles of legal formalism as "consistency, coherence, and stability, rather than any reference to ... external political or economic forces").

43 See Segal, 91 Am Polit Sci Rev at 28 (cited in note 25).

44 See Vicki Been, Locally Undesirable Land Uses in Minority Neighborhoods: Disproportionate Siting or Market Dynamics?, 103 Yale L J 1383, 1398-1406 (1994) (evaluating existing empirical evidence on the relationship between race and locally undesirable land uses and concluding that further research is needed); Vicki Been, Analyzing Evidence of Environmental Justice, 11 J Land Use \& Envir L 1, 8-21 (1995) (pointing out assumptions and methodological choices that obscure or exaggerate the problems of environmental justice); Vicki Been and Francis Gupta, Coming to the Nuisance or Going to the Barrios?: A Longitudinal Analysis of Environmental Justice Claims, 24 Ecol L Q 1, 9-19 (1997) (describing the article's empirical methodology that corrects for problems with studies existing at the time).

45 See Been, 103 Yale $L J$ at 1392-97 (cited in note 44).

46 See id at $1384-85$.

47 See Been, 24 Ecol L Q at 9-19 (cited in note 44). 
with situations in which the chosen unit-census tracts-changes over time. The article also introduces an important variable-population density - to control for the possibility that sites are less likely to be located in denser areas. Because data on density was not available for two of the decades of the study, Been constructed a proxy for that variable. Another of her articles is self-consciously devoted, almost

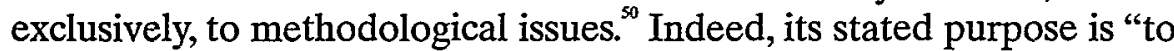
highlight the methodological issues researchers need to address, and to present alternative methodologies that should improve our ability to understand the nature of the distribution of environmental 'goods' and 'bads.","s1

Casting only a slightly larger net extending beyond my family, in an article forthcoming in the Journal of Financial Economics ${ }^{52}$ and available on the Social Science Research Network ${ }^{53}$ since February 2000, my colleague Robert Daines makes a significant methodological advance that permits him to test whether incorporation in Delaware increases firm value-a question that scholars have long debated. An important prior study had examined stock price reactions to the announcement that a firm would reincorporate in Delaware. ${ }^{\text {st }}$ Because such changes are often accompanied by changes in business strategy, however, it is difficult to determine whether the change in price reflects the reincorporation or the change in business practice. Also, such studies cannot shed light on how the decision to incorporate in a particular state affects the value of firms that do not reincorporate. Scholars thus continue to disagree about Delaware's impact on firm value.

Daines's methodological innovation was to study the effect of incorporation in Delaware on a firm's Tobin's Q-the ratio of a firm's market value to the replacement cost of its assets-thus allowing him to examine all public firms and avoid the selection bias and identification problems that affected all prior studies. He finds that the

48 Id at $10-16$.

49 Id at 23.

50 Been, $11 \mathrm{~J}$ Land Use \& Envir L at 4 (cited in note 44).

51 Id.

52 Robert Daines, Does Delaware Law Improve Firm Value?, 62 J Fin Econ 525 (2001).

53 Robert Daines, Does Delaware Law Improve Firm Value?, Columbia Law School Center for Studies in Law and Economics Working Paper No. 159 (2000), available online at $<$ http://papers.ssrn.com/sol3/papers.cfm?abstract_id=195109> (visited Jan 11, 2002). The SSRN database was one of Epstein and King's sources for empirical legal scholarship. See Epstein and King, $69 \mathrm{U}$ Chi L Rev at 16 \& $\mathrm{n} 39$ (cited in note 1).

54 See Roberta Romano, Law as Product: Some Pieces of the Incorporation Puzzle, $1 \mathrm{~J} \mathrm{~L}$, Econ, \& Org 225, 268-73 (1985). For a more recent study of this type in finance literature, see Randall A. Heron and Wilbur G. Lewellen, An Empirical Analysis of the Reincorporation Decision, 33 J Fin \& Quant Analysis 549 (1998) (examining the effects of reincorporation in new states on shareholder wealth and the firm's ability to attract outside directors). 
Tobin's $Q$ of Delaware firms is higher, thereby supporting the hypothesis that Delaware law improves firm value. Daines shows that the result is statistically significant and robust to controls for company size, industry, growth opportunities, diversification, financial performance, and unobservable firm heterogeneity. ${ }^{55}$ Thus, this method provides the first large-sample evidence of the relationship between law and firm value.

It may be that I am extraordinarily fortunate to have been able to spend time with a spouse and colleagues who performed the only empirical studies by legal academics that make important methodological advances. The far more likely scenario, however, is that a broader review of the legal literature would reveal many such examples. That Epstein and King could have done an extensive search of the legal literature and found no examples of this kind is therefore far more damning of the quality of their review than it is of the quality of the legal literature.

\section{MISPLACED CRITICISMS}

It is not possible in the space allocated to this Response to examine the validity of all of Epstein and King's complaints about empirical legal scholarship. I will instead focus on their extensive attacks on my work on judicial behavior in the D.C. Circuit. In particular, they complain about my choice of proxy for judicial ideology and my coding of the disposition of cases. All of Epstein and King's criticisms are unwarranted.

It is possible, of course, that they erred only with respect to my article and that their criticisms of the rest of the empirical legal scholarship were well taken. The reader, once again, will have to decide whether such a scenario is plausible.

\section{A. Choice of Proxy for Judicial Ideology}

Epstein and King devote a great deal of energy to attacking my proxy for judicial ideology - the views generally held by the party of the appointing president. They concede that this is "surely a reliable measure" but complain that it is not necessarily a "valid" measure because it does not take into account what they consider to be the important role of senatorial courtesy in determining the composition of the lower federal courts. ${ }^{\text {.6 }}$ According to Epstein and King, "[this] important institutional feature of the appointment process ... may have the effect of constraining the President from nominating a candidate 
to the lower federal courts who mirrors his ideology." They maintain that "when a senator is of the same party as the President and the vacancy is from the senator's state, the senator can exert considerable influence on the selection of judges."

There is one fatal problem with their criticism. My study is of the D.C. Circuit. The District of Columbia is not (at least for the time being) a state. It does not have any senators. Nobody exercises senatorial courtesy with respect to appointments to the D.C. Circuit. In fact, one of the reasons that particular judges get appointed to the D.C. Circuit as opposed to other courts is to get around the opposition of the senators from their home states. For example, in 1985, President Reagan abandoned an effort to place James Buckley on the Second Circuit, in part because of the opposition of Senator Lowell Weicker of Connecticut, where Buckley was a resident and from where he had run unsuccessfully for the U.S. Senate in 1980. Instead, President Reagan nominated Buckley to the D.C. Circuit. ${ }^{59}$ It is quite likely that other nominees get placed on the D.C. Circuit because the senators from their home states have other ideas about whom they wish to place on their regional circuits.

But even if my study had been of one of the regional circuits, for which there are senators who can demand senatorial courtesy, Epstein and King's criticisms would still be unwarranted. Using the party of the appointing president as a proxy for ideology is a standard technique in political science studies of judicial behavior. ${ }^{60}$ In fact, one recent study reviewed "[o]ne hundred forty books, articles, dissertations, and conference papers ... in the legal and political science literatures between 1959 and 1998 reporting empirical research pertinent to a link between judges' political party affiliation and judicial ideology.", The author notes that "investigations of the federal bench often look at the party of appointing presidents" instead of the party affiliations of the judges (which are often difficult to determine). ${ }^{62}$ A substantial proportion of the works reviewed are in the political science literature.

57 Id at 89.

58 Id at 95.

59 See Michael Oreskes, James Buckley to Be Washington Court Nominee, NY Times A1 (Oct 9, 1985) ("Senator Weicker told associates that he felt that Mr. Buckley was not qualified and that Mr. Buckley, who lives in Connecticut, had not contributed to building the Republican Party in the state.").

60 See Tracey E. George, Developing a Positive Theory of Decisionmaking on U.S. Courts of Appeals, 58 Ohio St L J 1635, 1651 (1998) ("[S]ocial scientists have discovered that the political party of the appointing President is a good proxy for a justice's attitudes.").

61 Daniel R. Pinello, Linking Party to Judicial Ideology in American Courts: A Metaanalysis, 20 Just Sys J 219, 219 (1999).

62 See id at 222.

63 See id at 243-54 (listing studies). 
Epstein and King may be right that also controlling for the views of the senators from the appointee's home state might be preferable. But for this proposition they rely on a study that had not yet been published, ${ }^{64}$ and that was not available even in working paper format at the time my article was published. Even if the District of Columbia had senators, it would still be odd to indict my piece for what still is the state-of-the-art methodology. The standard approach of the social sciences to a methodological innovation is to perform a new study to ascertain whether the innovation has an impact on the previous results, not to excoriate prior studies for not having used it. ${ }^{6}$

More generally, Epstein and King seem confused about the design of studies of judicial behavior and perhaps for this reason they complain about my choice of proxy. For example, they note that "the empirical record demonstrates that the voting propensities of the appointees of some Democratic and Republican presidents do not differ significantly." They claim, as a result, that the ideology of the appointing president is a bad proxy for judicial ideology. But it could be, instead, that the proxy is good but that judges are not being influenced by their ideology in deciding cases. Studies of judicial behavior should choose the best available proxy for judicial ideology, and then test whether this proxy is correlated with judicial votes. As indicated above, the standard proxy in the political science literature is determined by reference to the views generally held by the party of the appointing president-that is, the proxy that I have used. Epstein and King generally prefer a measure derived from newspaper editorials about Supreme Court nominees. ${ }^{67} \mathrm{I}$ have indicated in my prior work

64 See Michael Giles, Virginia Hettinger, and Todd Peters, An Alternative Measure of Preferences for Federal Judges, 54 Polit Rsrch Q 623 (2001) (cited in Epstein and King, 69 U Chi L Rev at 88 n 279, 89 n 281, 95 nn 301, 304 (cited in note 1)).

65 Epstein and King also present my article as an example of the problems that arise "when researchers have not clearly specified their theory." Epstein and King, $69 \mathrm{U}$ Chi L Rev at 74 (cited in note 1). As evidence of this methodological malfeasance they quote the following sentences from my article: "'Some commentators have ... maintained that judges simply vote according to their policy preferences. In environmental cases, the allegation goes, judges appointed by Republican Presidents vote principally for laxer regulations and judges appointed by Democratic Presidents for more stringent regulation."' Id, quoting Revesz, 83 Va L Rev at 1717 (cited in note 9). They claim that this passage is ambiguous as to how the independent variable defining a judge's ideology would be constructed. Epstein and King, 69 U Chi L Rev at 74-75 (cited in note 1). But those sentences merely purport to summarize the prior literature. The very next sentence states precisely how I will perform the test: "[by] using as a proxy the views generally held by the party of the appointing President." Revesz, 83 Va L Rev at 1718 (cited in note 9). Epstein and King understand that. See Epstein and King, $69 \mathrm{U}$ Chi L Rev at 75, 83, 86 (cited in note 1).

66 Epstein and King, $69 \mathrm{U}$ Chi L Rev at 88 (cited in note 1), citing Giles, Hettinger, and Peppers, 54 Polit Rsrch Q 623 (cited in note 64).

67 See Epstein and King, 69 U Chi L Rev at 90-91 (cited in note 1) (advocating the measure used in Jeffrey A. Segal and Albert D. Cover, Ideological Values and the Votes of U.S. Supreme Court Justices, 83 Am Polit Sci Rev 557, 559 (1989)). 
that "this methodology is unlikely to be usable for court of appeals judges, whose nominations typically receive less media attention" than those of Supreme Court justices. ${ }^{6 .}$ Epstein and King do not contest my claim in this regard. ${ }^{69}$ Instead, they propose a measure, advocated by a forthcoming study, that takes account of senatorial courtesy. But, as explained above, such a measure is simply inapplicable to the D.C. Circuit.

\section{B. Coding of the Disposition of Cases}

Epstein and King also criticize the manner in which I coded the disposition of cases. They note, "While he tells us that he treats 'remands' as 'reversals,' he does not report how he characterizes" other dispositions. ${ }^{70}$ In particular, they complain that a researcher attempting to replicate my study would not know whether to "characterize an 'affirmed in part, vacated in part, and remanded' as a reversal or an affirmance." $"$ They purport not to know how I would have coded such a case: "Neither the researcher nor we can answer that question because Revesz does not tell us." ${ }^{\text {"2 }}$ In fact, any researcher seeking to replicate my study would not have any such problem. My published work contains references to both the coding protocol used for my study and to the notes explaining the manner in which cases were coded, and indicates that these documents are both publicly available from the journal that published my article. ${ }^{73}$ In particular, the protocol and accompanying notes make clear that only full affirmances are treated as affirmances. ${ }^{74}$

Epstein and King also complain that even if I had been interested in studying whether cases were affirmed on the one hand, or reversed or remanded on the other, it would have been better to start with a more detailed specification of the outcomes. ${ }^{75}$ That is precisely what I did. As they suggest, my coding protocol contains different entries for "Reverse/Remand" and for "Reverse/Remand in part." " Also, as they

68 See Richard L. Revesz, Ideology, Collegiality, and the D.C. Circuit: A Reply to Chief Judge Harry T. Edwards, 85 Va L Rev 805, 824 n 102 (1999).

69 See Epstein and King, $69 \mathrm{U}$ Chi L Rev at $88 \mathrm{n} 276$ (cited in note 1).

70 See Epstein and King, $69 \mathrm{U}$ Chi L Rev at 84 (cited in note 1).

71 Id at 86.

72 Id at 85 .

73 See Revesz, 85 Va L Rev at 820 n 87 (cited in note 68).

74 See Richard L. Revesz, Notes on the Coding Protocol for Empirical Study of the D.C. Circuit 4, question 41, cited in Revesz, 85 Va L Rev at 820 n 87 (cited in note 68); Notes on the Coding Protocol at 5, question 41, cited in id.

75 See Epstein and King, 69 U Chi L Rev at 83-85 (cited in note 1).

76 See Revesz, Notes on the Coding Protocol at 4, question 41, cited in Revesz, $85 \mathrm{Va} \mathrm{L} \mathrm{Rev}$ at 820 n 87 (cited in note 68); Notes on the Coding Protocol at 5, question 41, cited in id. The notes also make clear that "[r] emanded but not reversed" is coded as "remand/reverse." 
would like, it splits cases up into a number of categories, by distinguishing between challenges to a substantive environmental policy and other cases." The accompanying notes indicate that the following outcomes "were not considered challenges to an EPA environmental policy . . .: 1. non-environmental challenges (attorney fees cases, employment cases, freedom of information cases, other types of regulations, funding cases); 2. court decisions involving voluntary dismissal or joint motion; 3 . housekeeping motions." ${ }^{78}$ Both the coding protocol and the accompanying notes reveal that if a case does not involve a challenge to a substantive environmental policy, it would not be used in the statistical analysis. ${ }^{79}$ Thus, Epstein and King are simply mistaken in raising concerns about whether my coding of the disposition of cases can be replicated, and are also wrong with respect to their quibbles about how I defined the number of possible case dispositions.

\section{THE INDICTMENT OF LEGAL SCHOLARSHIP}

Epstein and King's indictment of legal scholarship exhibits many of the same methodological failures that they attribute to law professors. First, their call for placing empirical legal scholarship in intellectual receivership, which is the central policy recommendation of their article, ${ }^{s a}$ could be justified only by some comparative evaluation of the methodological practices of legal and social science scholars. Epstein and King never attempt such a comparative inquiry.

It may well be the case that empirical legal scholarship is in bad shape. But how do we know that social scientists do not engage in the same, or other, pitfalls when they write about law-related subjects? Indeed, in the examples given in Part I of my work, and of Been's and Daines's work, the literature those studies improved upon was by social scientists. Any well-designed empirical study would have to make an assessment of practices among social scientists. Indeed, many of the methodological ills that they attribute to legal scholarship, such as explaining in detail how cases are coded or archiving data in generally

77 See Revesz, Notes on the Coding Protocol at 1, question 9, cited in Revesz, 85 Va L Rev at $820 \mathrm{n} 87$ (cited in note 68).

78 Revesz, Notes on the Coding Protocol at 2, question 9, cited in Revesz, 85 Va L Rev at 820 n 87 (cited in note 68). "Housekeeping motions" include requests concerning the filing of briefs and the time allocated to oral argument.

79 Revesz, Notes on the Coding Protocol at 1, question 9, cited in Revesz, 85 Va L Rev at $820 \mathrm{n} 87$ (cited in note 68); Revesz, Notes on the Coding Protocol at 2, question 9, cited in id.

80 See text accompanying notes 6-8.

81 They do say in passing that they "do not mean to suggest that empirical research appearing in law reviews is always, or even usually, worse than articles in the journals of other scholarly disciplines." Epstein and King, 69 U Chi L Rev at 18 (cited in note 1). But their recommendations make sense only if empirical legal scholarship is, in fact, a great deal poorer than its counterpart in the social sciences. 
accessible repositories, are not exclusive to legal scholarship. First, recall Epstein and King's complaint-unjustified, it turned out-that I did not explain whether remands in part were treated in the same manner as remands in full. ${ }^{22}$ Complications of this type are not discussed in prominent social science studies, which code cases as prounion or anti-union, ${ }^{8}$ or liberal or conservative. ${ }^{84}$

Second, Epstein and King are quite unclear about the scope of their claim, because the authors criticize articles in a wide variety of categories. Many of the articles with which they find fault were written by law professors and published in law reviews; they describe their empirical design as a "survey of current practices in the nation's law reviews." ${ }^{\star s}$ But others were written by law professors and published in peer-reviewed, interdisciplinary journals. ${ }^{80}$ The supposedly poor quality of these pieces cannot be attributable to the editorial practices of student-run law reviews. ${ }^{87}$ Moreover, it would be odd if the peerreviewed journals systematically published bad empirical research by lawyers and good empirical research by social scientists. Yet other pieces that the authors criticize were coauthored by legal academics and social scientists. ${ }^{88}$ In fact, such collaboration is exactly what Epstein and King prescribe elsewhere in their article: "[L]aw professors can learn on the job by entering into collaborations with a methodologist in the law school or colleagues with an interest in law in, say,

\footnotetext{
82 See text accompanying notes 70-74.

83 See Spiller and Gely, 23 RAND J Econ at 474 (cited in note 25) (classifying Supreme Court decisions as "pro-union").

34 See Segal, 91 Am Polit Sci Rev at 36 n 27 (cited in note 25) (defining cases as "liberal"); Caporale and Winter, $35 \mathrm{~J}$ Econ Beh \& Org at 466 (cited in note 25) (assigning decisions a binary variable corresponding to whether or not the decision is liberal).

85 See Epstein and King, 69 U Chi L Rev at 15 (cited in note 1).

86 Epstein and King indicate that they examined studies in four peer-reviewed journals. See id at 16.

87 Epstein and King are critical of law reviews and devote considerable attention to suggesting an alternative model of scholarly journal management. See id at 125-30.

88 See id at 39-41 (discussing Theodore Eisenberg, Stephen P. Garvey, and Martin T. Wells, Jury Responsibility in Capital Sentencing: An Empirical Study, 44 Buff L Rev 339 (1996)); id at 56-57 (discussing Gregory Sisk, Michael Heise and Andrew Morriss, Charting the Influences on the Judicial Mind: An Empirical Study of Judicial Reasoning, 73 NYU L Rev 1377 (1998)); id at 52-53 (discussing Vicki Schultz and Stephen Petterson, Race, Gender Work, and Choice: An Empirical Study of the Lack of Interest Defense in Title VII Cases Challenging Job Segregation, 59 U Chi L Rev 1073 (1992)); id at 87-89, 95-96 (discussing Cross and Tiller, 107 Yale L J at 2155 (cited in note 35)). Wells is Professor of Statistics in the Department of Social Statistics at Cornell University. He obtained a Ph.D. in mathematics on the basis of a dissertation on empirical methodology entitled Contributions to the Theory of Goodness of Fit Testing. Heise and Morriss both have Ph.D.s in the social sciences; Morriss is also an associate professor of economics at Case Western Reserve University. Petterson was a doctoral candidate in sociology at the time the article was written, and later became an assistant professor of sociology at the University of Virginia. Tiller has a Ph.D. in the social sciences and holds an academic appointment at the University of Texas Business School.
} 
one of the social sciences., ${ }^{, 89}$ If this model does not work either, why should we expect that Epstein and King's solution of placing legal scholarship in intellectual receivership will be more successful? One of the articles criticized as an example of poor legal scholarship was written by one of the nation's leading empirical social scientists, who does not have a law degree.

More generally, because Epstein and King never explain how they define the universe of works that they evaluate, their study suffers from the same types of replication problems that they attribute to legal scholarship: other researchers would simply not know what works Epstein and King considered."

Third, the Epstein and King study suffers from another serious replication problem: it never explains with any clarity what it means by lack of "self-conscious attention to methodology" -one of the primary evils that it attributes to legal scholarship. As a result, it is likely that if other researchers tried to replicate the study, they would not use the same metric. Rather, to use Epstein and King's own phrase in indicting other scholarship, the researcher "would have to make a judgment call ... [that] detracts from the reliability of [the] measure.",

For example, I believe that my article on judicial behavior on the D.C. Circuit, which is discussed in Part I, is "self-conscious" as to methodology, and presents a detailed analysis for why this is so. Epstein and King evidently believe otherwise. The fault lies with the cavalier manner in which they formulate their indictment of empirical legal scholarship. In summary, their work suffers from precisely the same flaws that they attribute to empirical legal scholarship: They "ignore[ ] the rules of inference and appl[y] instead the 'rules' of persuasion and advocacy," even when the goals "[are] to learn about the empirical world."

\section{INTERDISCIPLINARY DIALOGUE}

Epstein and King present a picture in which legal scholars do their work in isolation from their counterparts in the social sciences and suffer greatly from this lack of dialogue. ${ }^{95}$ One of their main prescriptions is that legal scholars doing empirical work spend more time talking to social scientists.

Epstein and King, 69 U Chi L Rev at 120 (cited in note 1)

90 See id at 77 n 254, discussing W. Kip Viscusi, The Social Costs of Punitive Damages against Corporations in Environmental and Safety Torts, 87 Georgetown L J 285 (1998).

91 See Epstein and King, $69 \mathrm{U}$ Chi L Rev at 38-45 (cited in note 1) (discussing replication).

92 Epstein and King, $69 \mathrm{U}$ Chi L Rev at 11 (cited in note 1).

93 Id at 85 .

94 Id at 9.

95 See id at $45-48$. 
Epstein and King's proposition concerning the desirability of interdisciplinary dialogue is certainly well taken. They are right that legal scholars clearly benefit from such dialogue, although, for reasons already discussed, they are wrong in believing that, with respect to empirical methodology, the benefits would flow in only one direction. ${ }^{96}$ But a world in which legal scholars operate in a vacuum, isolated from their social science counterparts, is not one that successful legal scholars would find recognizable. The institutions that Epstein and King would like to create already exist, and are flourishing. I will proceed in a somewhat autobiographical manner by focusing on those institutions from which I derive principal benefits.

First, I am fortunate that my home institution, the New York University School of Law, has an ongoing Colloquium on Law, Economics, and Politics, which meets biweekly throughout the academic year. The colloquium is run by John Ferejohn, of the Political Science Department and Hoover Institution at Stanford University, and my colleague Lewis Kornhauser, who has a Ph.D. in economics as well as a law degree. It is attended on a regular basis by a number of my colleagues on the law faculty as well as by distinguished political scientists from NYU and elsewhere.

Second, in recent years, the annual meeting of the American Law and Economics Association has included a panel on Positive Political Theory. The panel organizer has generally been a political scientist and the presenters have been both legal and social science scholars.

Third, a major conference on the Economics of Courts held at Harvard University in 1997 brought together leading scholars in law, economics, and political science doing empirical and theoretical work on judicial behavior. The hallway conversation at that meeting was partly about the gradual emergence of a single community of individuals working on similar issues in different parts of the university, and the increasing synergies resulting from such work.

Fourth, the Journal of Law, Economics, \& Organization, edited by Alan Schwartz of the Yale Law School, serves as a critically important outlet for work on judicial behavior. Over the years, it has published the proceedings of two influential conferences on political institutions, ${ }^{97}$ as well as a number of the leading articles on judicial behavior by legal and social science academics.

96 See id at 119-21. They note, for example, that perhaps law schools "could hold a monthly seminar on applications and innovations in empirical methodology, inviting prominent scholars (for now, from other disciplines) to lead them." Id at 121 (emphasis added).

97 See Conference on the Economics and Politics of Administrative Law and Procedures, $8 \mathrm{~J}$ L, Econ, \& Org (1992); Conference on The Organization of Political Institutions, $6 \mathrm{~J} \mathrm{L,} \mathrm{Econ,} \mathrm{\&}$ Org (1990).

98 See, for example, Gregory A. Caldeira, John R. Wright, and Christopher J.W. Zorn, So- 
My experience certainly is not unique. A number of my corporate law colleagues, for example, regularly interact with finance scholars in economics departments and business schools. They have created vigorous and successful institutions to sustain and encourage such debate. Interdisciplinary annual meetings that regularly draw a substantial number of legal and social science academics include those organized by the American Law and Economics Association, the Law and Society Association, and the Public Choice Society. Moreover, as Epstein and King recognize, there are a number of interdisciplinary peerreviewed journals in which both legal and social science academics publish their work."

Epstein and King appear to have simply missed what may be the most important intellectual development in legal scholarship in the last couple of decades: its gradual integration with other parts of the academy.

\section{CONCLUSION}

Epstein and King are right about some of the criticisms that they level against the institutions of legal scholarship. Undoubtedly, some empirical studies are poorly designed and executed. In general, law professors do not have access to a stable cadre of student assistants well trained in empirical methodology. Some law professors may work in an excessively insulated environment and do not benefit from necessary collegial interactions with social scientists. Most student editors on law reviews are probably not well equipped to judge whether empirical studies were well conducted-though they might be able to judge the importance of the question being examined.

But, at the same time, empirical legal scholarship has a great deal to contribute to the understanding of law and legal institutions, and social scientists would benefit from paying close attention to the methodological innovations performed by legal scholars. Because of

\footnotetext{
phisticated Voting and Gate-Keeping in the Supreme Court, $15 \mathrm{~J}$ L, Econ, \& Org 549 (1999) (analyzing the "sophisticated voting" of the Supreme Court through a combination of social science and legal techniques); Pablo T. Spiller and Matthew L. Spitzer, Where Is the Sin in Sincere?: Sophisticated Manipulation of Sincere Judicial Voters (with Applications to Other Voting Environments), $11 \mathrm{~J} \mathrm{~L}$, Econ, \& Org 32 (1995) (combining traditional "sophisticated voting" models with a "sincere voting" model to evaluate judicial decisionmaking); Edward P. Schwartz, Policy, Precedent, and Power: A Positive Theory of Supreme Court Decisionmaking, $8 \mathrm{~J}$ L, Econ, \& Org 219 (1992) (using a combination of legal and social science techniques to create a model of Supreme Court decisionmaking that accounts for both policy preferences and precedent); Rafael Gely and Pablo T. Spiller, A Rational Choice Theory of Supreme Court Statutory Decisions with Applications to the State Farm and Grove City Cases, 6 J L, Econ, \& Org 263 (1990) (developing a rational choice theory of the Supreme Court by combining the rational choice model with the notion that institutions matter in the design of public policy).

99 See Epstein and King, 69 U Chi L Rev at 16 (cited in note 1).
} 
their flawed methodology and unwarranted criticisms and exaggerations, Epstein and King have missed an important opportunity to examine what legal and social science empirical scholarship can learn from one another. 


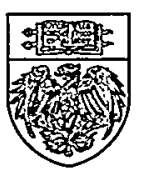

